\title{
Aphakia korrekciója irisklip múlencse retropupillaris beültetésével
}

\author{
Szabó Antal dr. - Papp András dr. - Borbándy Ágnes dr. \\ D. Géhl Zsuzsanna dr. - Nagy Zoltán Zsolt dr. - Resch Miklós dr. \\ Semmelweis Egyetem, Általános Orvostudományi Kar, Szemészeti Klinika, Budapest
}

\begin{abstract}
Bevezetés és célkitüzés: Az aphakia mútéti korrekciója sokszor komoly kihívás az operatő́r számára. A szerzők célja a retropupillarisan beültetett irisklip múlencsékkel szerzett tapasztalataik ismertetése. Módszer: A 2014. január l. és 2015. december 31. közötti eseteket gyújitötték össze retrospektív módon. Azokat a betegeket vonták be a tanulmányba, akiknél retropupillarisan irisklip VRSA 54 (AMO Advanced Medical Optics, Amerikai Egyesült Államok) beültetését végezték el. A betegek követési ideje legalább három hónapos volt. Értékelték a múlencse stabilitását, a mútéti és mútét utáni szövődményeket és a betegek látóélességét. Eredmények: A fenti időszakban 11 esetben (egy nő, tíz férfi) végeztek ilyen beavatkozást. A mútét idején a betegek átlagéletkora 57,7 év volt (25-74 év). Négy esetben primer, hét esetben szekunder beültetést végeztek. A múlencse az irishez minden esetben rögzíthetô volt. A mútét előtti legjobb korrigált látóélesség $0,43(0,1-1,0)$, a követési idő végén $0,49(0,04-1,0)$ volt. Következtetések: A rertopupillarisan beültetett iriskliplencse-implantációval a betegek minden esetben jól rehabilitálhatóak voltak. Orv. Hetil., 2017, 158(1), 20-24.
\end{abstract}

Kulcsszavak: retropupillaris iriskliplencse-beültetés, aphakia

\section{Correction of aphakia with the implantation of the retropupillary iris clip intraocular artificial lens}

\begin{abstract}
Introduction and aim: The correction of aphakia might be a challenge for the surgeon. The aim of this study is to describe the authors' experience with the implantation of the retropupillary iris clip intraocular lens. Method: Patients between January 2014 and December 2015 were included in the retrospective study. Retropupillary implantation of iris clip intraocular lens VRSA 54 (AMO Advanced Medical Optics, USA) was performed in all cases. The minimum follow up period was three months. The stability of the intraocular lens and the intraoperative and postoperative complications and the visual acuity were evaluated. Results: During this time period 11 cases ( 1 female, 10 males) were included in the study. The mean age at the time of the implantation was 57.7 years (between $25-74$ years). In 4 cases the iris clip lens was implanted during the first intervention, in 7 cases during the secondary procedure. In all cases the lens was fixated onto the iris posteriorly. The best corrected visual acuity before the iris clip implantation was $0.43(0.1-1.0)$ and postoperatively at the time of the follow up $0.49(0.04-1.0)$. Conclusions: With the use of the retropupillary implanted iris clip intraocular lens all of the patients could have been rehabilitated without major complications.
\end{abstract}

Keywords: retropupillary implanted iris clip intraocular lens, aphakia

Szabó, A., Papp, A., Borbándy, Á., D. Géhl, Zs., Nagy, Z. Zs., Resch, M. [Correction of aphakia with the implantation of the retropupillary iris clip intraocular artificial lens]. Orv. Hetil., 2017, 158(1), 20-24.

(Beérkezett: 2016. szeptember 7.; elfogadva: 2016. november 5.)

A szürkehályog-mútét során múlencse hiányában évszázadokig elfogadott állapotnak tekintették az aphakiát. A lencsehíjas állapot azonban a korszerü szürkehályogsebészet korában már korrigálható, azonban az aphakia sokszor nehéz feladat elé állítja az operáló szemsebészt [1].

A mai mikrosebészeti lehetőségek mellett is létrejöhet az elülső és a hátsó tok jelentős sérülése. Előfordulhat a 
korábban beültetett múlencse tokkal együtt történő subluxatiója, diszlokációja, illetve teljes luxatiója is. Ennek oka lehet mútét alatti zonulasérülés, a szemgolyót ért utólagos sérülés vagy szisztémás betegség fennállása (például Marfan-szindróma vagy exfoliatio) [2,3].

A szemlencse tokjának jelentős sérülése igen gyakran fordulhat még elő áthatoló sérülések következtében is, amikor az elülső szegmentum súlyos sérülése a szemlencse tokjára is kiterjed. Ezekben az esetekben a sebésznek meg kell terveznie - az elérhető maximális látásjavulás érdekében - a rehabilitáció lépéseit [4].

Amennyiben a lencsefüggesztő rostok (zonulák) 360 fokban sérültek vagy több mint kétharmad részük elszakadt, illetve kiterjedt toksérülést észlelünk, az esetben különböző rekonstrukciós mütéti megoldások állnak az operatőr rendelkezésére. Az egyik megoldás a múlencse elülső csarnokba való beültetése, úgynevezett elülsőcsarnok-múlencsével (anterior chamber lens - ACL). Ennek a mütéti megoldásnak egyik lehetséges szövődménye a mútét utáni fokozatos endothelveszteség, bár a jelenleg forgalomban lévő ACL-múlencsék mellett ez már kisebb mértékben játszik szerepet, mint ami a korábban használatos múlencsékkel megfigyelhető volt [5].

Rögzíthetjük a múlencse hapticáit fel nem szívódó varratokkal az irishez, illetve a sclerához is $[6,7]$. Ezekben az esetekben számolnunk kell a mútéti technika esetleges késői következményeivel: az irisirritáció miatt következményes uveitis, szekunder glaucoma előfordulása figyelhető meg az esetek egy részében. Rögzíthetjük a múlencsét intrascleralis alagútsebben, varrat nélkül is. Ez a fajta mütéti megoldás nagy sebészi tapasztalatot, hosszú tanulási görbét igényel az operatőrtől [8].

$\mathrm{Az}$ aphakia korrekciójának további lehetséges megoldása az úgynevezett irisklip múlencse alkalmazása, beültetése. Az irisklip múlencse első prezentációja 1971-ben, Worsttól származik [9]. A Worst által beültetett bikonvex polimetil-metakrilát múlencse az elülső csarnokban helyezkedett el, a hapticák két ponton az irishez elölről kapcsolódtak. Az 1980-as évek elején Amar publikálta először a múlencsének a hátsó csarnokba történő úgynevezett retropupillaris implantációját [10], amelynek során a múlencse optikája a pupilla mögött helyezkedik el és hapticái az irishez hátulról kapcsolódnak. A múlencsével kapcsolatos első klinikai eredményeket 1994-ben Rijneveld közölte [11]. Ezt követően a technika 2002 után, Mohrnak köszönhetően vált népszerüvé [12]. Az operatőrök között jelenleg heves vita folyik arról, hogy a praepupillaris vagy retropupillaris implantáció az előnyösebb.

Közleményünk célja a retropupillarisan beültetett irisklip múlencsékkel szerzett tapasztalataink ismertetése.

\section{Módszer}

A Semmelweis Egyetem, Szemészeti Klinika beteganyagából retrospektív módon gyưjtöttük össze azoknak a betegeknek az adatait, akiknél 2014. január 1. és 2015. december 31. között retropupillaris irisklip Verisyse VRSA 54 múlencse (AMO Advanced Medical Optics, Amerikai Egyesült Államok) beültetését végeztük el. A múlencse anyaga polimetil-metakrilát, amely merev, kemény, a múlencse nem összehajtható (1. ábra).

A mütét előtt biometriát végeztünk standard módon, figyelembe vettük azt, hogy különböző A-konstanssal kell számolni a múlencse prae- vagy retropupillaris beültetése kapcsán. Esetünkben a 116,8 A-konstans értékkel számoltunk.

A mútétet kilenc esetben retrobulbaris érzéstelenítésben, két esetben altatásban végeztük.

Négy beteg esetében komplikált cataractamútét során a szürke hályog eltávolítása után, egy ülésben, primer módon hajtottuk végre a múlencse-implantációt. További hét betegnél a múlencse-beültetést szekunder módon végeztük el. A primer mütétek esetén a beavatkozást három esetben, a szekunder mútétek esetén két szem esetében kombináltuk parsplana-vitrectomiával.

A mütéti technika a következő lépéseket tartalmazta (2. ábra):

- Clear cornealis sebet $(6,0 \mathrm{~mm})$ készítettünk XII h-s helyzetben. III és IX h-nál pedig cornealis segédnyílásokat készítettünk a múlencse manipulációjának megkönnyítésére. Elülső vitrectomia vagy teljes vitrectomia elvégzése után a beszúkített pupilla mellett viszkoelasztikus anyaggal töltöttük fel az elülső csarnokot, illetve a retroiridalis területet.

Speciális lencsefogó csipesz segítségével helyeztük a múlencsét az iris mögé, az iris szövetét a lencse hapticái közé pedig mikrospatulával helyeztük be [11-13].

- A corneasebet tovafutó 10/0 nejlonvarrattal zártuk.

Azoknak a betegeknek az adatait elemeztük, akiknél a követési idő legalább három hónapos volt. Eseteinkben az átlagos követési idő hat hónap volt (3-13 hónap).

\section{Eredmények}

Összesen 11 esetben ültettünk be retropupillarisan irisklip múlencsét. Betegeink között tíz férfi, illetve egy nő volt. A mütét idején a betegek átlagéletkora 57,7 év volt (25-74 év) (1. táblázat).

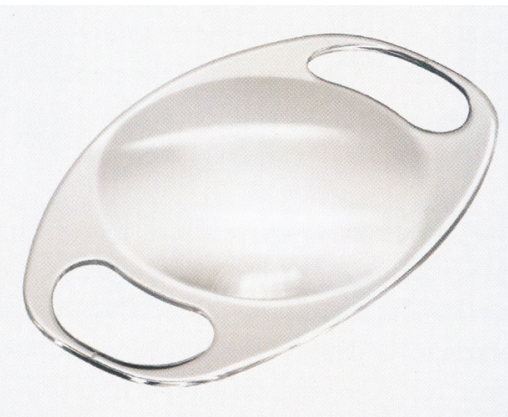

1. ábra A múlencse felülnézeti képe. A PMMA UV-szűrővel ellátott múlencse optikai átmérője $5 \mathrm{~mm}$. Teljes külső átmérője $8,5 \mathrm{~mm}$. +2,0-tól +30,0 dioptriáig érhető el

(http://www.opc.hu/hu/64-6116.html) 


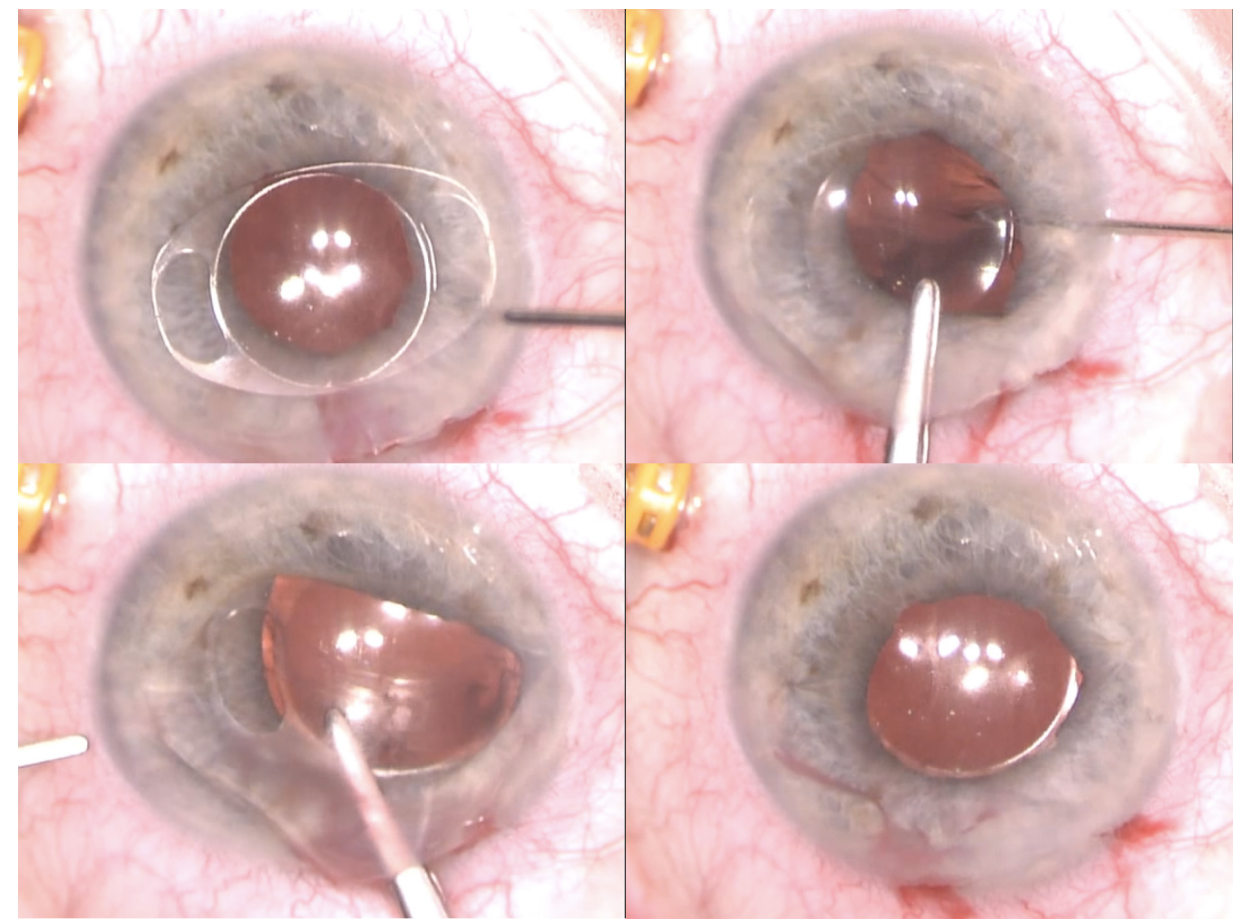

2. ábra $\quad$ A múlencse implantációjának egyes lépései

Az általunk elemzett időszak alatt a vizsgálatba beválogatott betegeinket két csoportba soroltuk. Az elsô csoportban lévő betegeinknél a lencsetok valamilyen trauma következtében sérült (három eset). Ezekben az esetekben kombinált mütét, parsplana-vitrectomia, illetve lencsemútét volt szükséges a sérülés primer ellátására. Két esetben a hátsó szegmentumot érintő súlyos sérülés volt megfigyelhető. Ezekben az esetekben a primer ellátás során az üvegtesti térből intraocularis idegen testet kellett eltávolítani. Az irisklip múlencse beültetése ezekben az esetekben szekunder módon történt (3. és 4. ábra).

A második csoportba tartozó nyolc betegnél az elülső, illetve hátulsó tok komplikált cataractamútét során sérült,

1. táblázat | Betegadatok

\begin{tabular}{|c|c|c|c|c|c|c|c|c|c|c|c|}
\hline $\begin{array}{l}\text { Monog- } \\
\text { ram }\end{array}$ & $\begin{array}{l}\text { Beteg } \\
\text { neme }\end{array}$ & Életkor & Mútét oka & $\begin{array}{l}\text { VRSA- } \\
\text { beültetésig } \\
\text { eltelt } \\
\text { hónapok }\end{array}$ & $\begin{array}{l}\text { Preoperatív } \\
\text { visus }\end{array}$ & $\begin{array}{l}\text { Poszt- } \\
\text { operatív } \\
\text { visus }\end{array}$ & $\begin{array}{l}\text { Mútéti } \\
\text { komplikáció }\end{array}$ & $\begin{array}{l}\text { Macula- } \\
\text { oedema }\end{array}$ & $\begin{array}{l}\text { Posztope- } \\
\text { ratív } \\
\text { IOP- } \\
\text { emelkedés }\end{array}$ & $\begin{array}{l}\text { Posztope- } \\
\text { ratív } \\
\text { szövőd- } \\
\text { mény }\end{array}$ & $\begin{array}{l}\text { Követés } \\
\text { (hónap) }\end{array}$ \\
\hline K. J. & Férfi & 51 & Aphakia & 3 & 0,1 & 0,6 & Nem volt & Nem volt & Nem volt & Nem volt & 3 \\
\hline B. Gy. & Férfi & 70 & $\begin{array}{l}\text { Phacodonesis, } \\
\text { cataracta }\end{array}$ & 0 & 0,15 & 0,32 & Nem volt & Nem volt & Nem volt & Nem volt & 10 \\
\hline L. O. Zs. & Nő & 51 & $\begin{array}{l}\text { Phacodonesis, } \\
\text { cataracta }\end{array}$ & 0 & 0,15 & 0,4 & Nem volt & Nem volt & Nem volt & Nem volt & 8 \\
\hline F. A. & Férfi & 66 & Luxatio PCL & 0 & 0,6 & 0,6 & Nem volt & Nem volt & Nem volt & Nem volt & 11 \\
\hline Sz. I. & Férfi & 64 & $\begin{array}{l}\text { PCL } \\
\text { elszürkülése }\end{array}$ & 0 & 0,8 & 1,0 & Nem volt & Nem volt & Nem volt & Nem volt & 7 \\
\hline H. I. & Férfi & 64 & $\begin{array}{l}\text { Subluxatio } \\
\text { PCL }\end{array}$ & 3 & 0,5 & 0,3 & Nem volt & Nem volt & Nem volt & Nem volt & 4 \\
\hline H. B. & Férfi & 52 & Aphakia & 3 & 0,8 & 0,8 & Nem volt & Nem volt & Nem volt & Nem volt & 3 \\
\hline B. A. & Férfi & 49 & Aphakia & 3 & 0,1 & 0,04 & Nem volt & Nem volt & Nem volt & Nem volt & 3 \\
\hline I. G. & Férfi & 25 & Sérülés & 3 & 0,4 & 0,16 & Nem volt & Nem volt & Nem volt & Nem volt & 3 \\
\hline V. B. & Férfi & 74 & Aphakia & 3 & 0,2 & 0,25 & Nem volt & Nem volt & Nem volt & $\begin{array}{l}\text { PCL- } \\
\text { subluxatio }\end{array}$ & 13 \\
\hline Sz. Á. & Férfi & 69 & Aphakia & 2 & 1,0 & 1,0 & Nem volt & Nem volt & Nem volt & Nem volt & 4 \\
\hline
\end{tabular}

IOP = intraocularis nyomás. 
s a maradék tok nem volt alkalmas sulcusba történő múlencse-beültetésre sem. Ebbe a csoportba soroltuk azokat a betegeket is, akiknél preoperatív phakodonesis miatt tervezetten intracapsularis hályogmútétet, illetve egyidejüleg múlencse-beültetést terveztünk, vagy korábbi mülencse-beültetést követően a múlencse üvegtesti térbe történő luxatiója miatt kényszerültünk múlencsecserére.

Négy esetben az első, primer mútét során beültettük a múlencsét, betegeink többségében, hét esetben szekunder módon került az irisklip múlencse beültetésre.

A múlencse az irishez minden esetben rögzíthető volt. Egy esetben figyeltük meg a múlencse posztoperatív diszlokációját. A primer beültetést követően erre hat hónappal később került sor. Ebben az esetben a diszlokáció feltételezhető oka az volt, hogy egy korábban sérült, at-

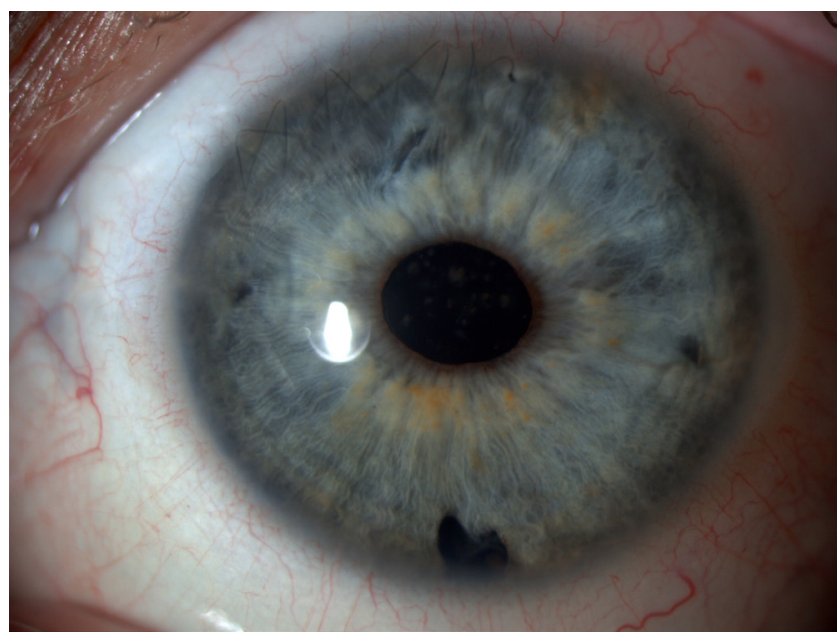

3. ábra

Áthatoló szemsérülés, intravitrealis idegen test, illetve ablatio retinae miatt phaco + vitrectomia + idegentest-eltávolítás + szi likonolaj-beültetést követően secunder módon ültettük be múlencsét. A második mútétnél végeztük el a szilikonolaj eltá volítását is. VI h-nál az Ando iridectomia nyoma, III és IX h-nál a lencse irishez való rögzítési pontjai látszik jól

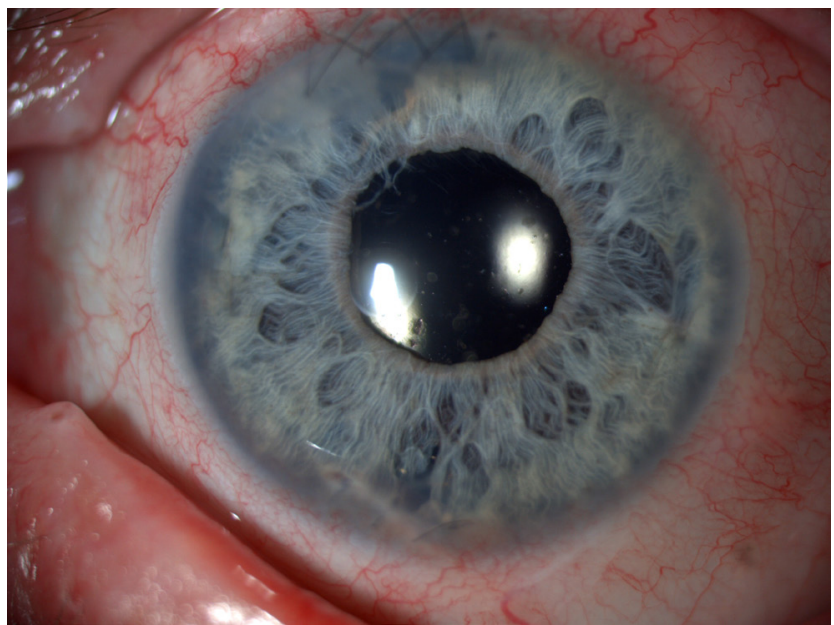

4. ábra

Áthatoló corneasérülést követően ültettük be az irisklip lencsét Jól látszik VI h-nál a primer sérülés helye, illetve XI-I h között, a corneasebnek megfelelően a tovafutó $10 / 0$ nejlonvarrat is rophiás irishez rögzítettük retropupillarisan az irisklipet. A beteg későbbi ellátása során (irisvarratok behelyezése, illetve pupillaképzés) a lencse immár ismét stabilan rögzíthető volt a szivárványhártyához. A beteg legutolsó mútétje után 22 hónap telt el, a múlencse helyzete jelenleg is stabil.

A lencsebeültetés előtt a legjobb korrigált látóélesség $0,43(0,1-1,0)$ volt. A követési idő végén a látóélesség $0,49(0,04-1,0)$ lett.

\section{Következtetések}

A retropupillarisan beültetett irisklip múlencse alkalmazása az elmúlt évtizedekben terjedt el, mint az aphakia korrekciójának egyik lehetséges megoldása [13, 14].

A múlencse beültetése viszonylag egyszerü, tapasztalt operatőr kezében gyorsan elvégezhető. A múlencse az iris síkja elé, illetve mögé is könnyen implantálható. Az elülső csarnokba ültetett múlencsével világszerte több tapasztalat áll rendelkezésre, így irodalma is bőségesebb, De Silva és mtsai közleményükben 116 esetrôl számolnak be, amelyeket - munkánkhoz hasonlóan - többségében másodlagosan ültettek be [15]. A praepupillarisan beültetett múlencsék esetén az endothelveszteség jelentősebb, míg a retropupillaris beültetés esetén pigmentdiszperzió előfordulásával lehet számolni mint esetleges késői szövődmény. Késői szövődmény lehet még a szekunder glaucoma is [12, 13]. A múlencse kezdetben Artisan néven került forgalomba, majd a Verysise elnevezésû következő generációs modell geometriáján már módosítottak annak érdekében, hogy a corneahátlaptól való távolság nagyobb legyen az endothelium védelme érdekében.

Gonnermann közleményében 137 hátsóiris-klip mülencse beültetésével szerzett tapasztalatairól számol be, amelyek hasonlóak saját, kisebb esetszámú vizsgálatunk eredményeihez: 7,3\%-ban primer beültetést, 69,4\%-ban múlencsecserét végeztek és 23,3\%-ban aphakiás szembe másodlagosan ültették be a múlencsét [16].

A beültetést követően az elhúzott, ovális pupilla előfordulása mintegy 5\%-ra tehető a mütét után, ez eseteink között nem fordult elő, Gonnermann 24,3\%-ban észlelte [16, 17]. Másik viszonylag gyakrabban előforduló posztoperatív szövődmény, amit meg kell említeni, a maculaoedema, illetve az irissynechiák előfordulása [12, 13]. Gonnermann maculaoedemát 8,7\%-ban talált. A mi anyagunkban biomikroszkóposan nem tapasztaltunk maculaoedemát, és a múlencséhez kóros irislenövés sem fordult elö.

Ritka esetekben előfordulhat a retropupillarisan beültetett irisklip múlencse subluxatiója, luxatiója, Gonnermann anyagában $8,7 \%$-ban fordult elő a múlencse egyik hapticájának diszenklavációja. Saját esetünk alapján úgy gondoljuk, hogy csak szabályos, jól reagáló pupilla esetén javasolt az implantáció, amikor is jelentős irissérülés nem volt elözetesen, illetve az iris szövete sem atrophiás. Schöpfer munkájában kimutatta, hogy a retropupillarisan 
beültetett irisklip múlencse helyzete változik a beteg fejtartásától függően, és mintegy $\pm 0,4 \mathrm{D}$ változást eredményezhet előre-, illetve hátrahajláskor [18]. Az ilyen jellegü fénytörés-ingadozásokat betegeink nem tapasztalták.

Preventív iridectomiát egyik esetben sem végeztünk. Szignifikáns szemnyomás-emelkedést egyik esetben sem tapasztaltunk, s pupillaris blokk sem alakult ki egyik betegünknél sem.

A mútét utáni látóélesség sok esetben nem érte el az 50-100\%-ot. Ennek magyarázata az egyéb szembetegségekben (például pseudoexfoliatiós glaucoma, súlyos sérülés vagy korábbi vitrectomia) keresendő, irodalmi hivatkozások alapján ebben nem mutatkozik különbség az irishez elölről vagy hátulról rögzített múlencse vonatkozásában [16, 17].

Hara és mtsai a retropupillarisan rögzített irisklip és a transscleralisan rögzített múlencséket összehasonlították több szempontból: a korai posztoperatív időszakban a látóélességet jobbnak tapasztalták az irisklip múlencse esetén, a mütéti idő pedig lényegesen rövidebb volt eseteikben [19].

Ebben a betegcsoportban nehézséget okoz a cornealis astigmia kérdése, hiszen szinte minden esetben korábbi sérülés vagy szövődményes szürkehályog-mütét előzi meg az irisklip múlencse beültetését, továbbá a beültetésben legalább 6,0 mm-es seb készítése szükséges a múlencse alapanyaga miatt. A fentieket figyelembe véve az astigmia elemzésétől eltekintettünk betegeink körében. $\mathrm{Az}$ irodalmi adatok szerint az aphakia miatt végzett bármilyen múlencse-beültetés esetén az astigmia akár a cornea állapota, akár a múlencse esetleges decentrálódása vagy ferde elhelyezkedése miatt jelentős kihívást jelent sikeres mútét ellenére is.

A szerzők egy frappáns, gyorsan kivitelezhető megoldásnak tartják a retropupillaris irisklip beültetését. A mütét adta előnyök jóval meghaladják a hátrányokat. A sebészi manipuláció, ezért az esetleges, következményes iatrogenitás kevesebb, mint akár az irishez, akár a sclerához, varrattal vagy scleratunnelbe, varrat nélkül rögzített múlencsék esetén megfigyelhető, így mindenképpen szorgalmazzuk a technika magyarországi elterjedését. A különféle technikák összehasonlító, nagy esetszámú vizsgálata segíthet majd eldönteni, vajon melyik az optimális megoldás aphakia korrekciójára.

Anyagi támogatás: A szerzők anyagi támogatásban nem részesültek.

Szerzői munkamegosztás: Sz. A.: A hipotézisek kidolgozása, a vizsgálat lefolytatása, a kézirat elkészítése, megszövegezése. P. A., B. Á., D. G. Zs.: A hipotézisek kidolgozása, a vizsgálat lefolytatása. N. Z. Zs.: A kézirat szövegezése, korrektúrája. R. M.: A kézirat megszövegezése. A cikk végleges változatát valamennyi szerző elolvasta és jóváhagyta.

Érdekeltségek: A szerzőknek nincsenek érdekeltségeik.

\section{Irodalom}

[1] Marsovszky, L.: History of cataract operations in Hungary. [A hályogoperálás története Magyarországon]. Orv Hetil., 2013, 154(45),1802-1805. [Hungarian]

[2] Miraldi Utz, V., Coussa, R. G., Traboulsi, E. I.: Surgical management of lens subluxation in Marfan syndrome. J. AAPOS, 2014, $18(2), 140-146$.

[3] Forlini, M., Soliman, W., Bratu, A., et al.: Long-term follow-up of retropupillary iris-claw intraocular lens implantation: a retrospective analysis. BMC Ophthalmol., 2015, 15, 143.

[4] Yalniz-Akkaya, Z., Burcu, A., Uney, G. O., et al.: Primary and secondary implantation of scleral-fixated posterior chamber intraocular lenses in adult patients. Middle East Afr. J. Ophthalmol., 2014, 2l(1), 44-49.

[5] Belkin, A., Ofir, S., Kleinmann, G., et al.: Iris Fixation of Unstable Anterior Chamber Intraocular Lenses. Cornea, 2015, 34(12), 1573-1576.

[6] Kerényi, Á., Dálnoki, N.: Secondary implantation of foldable posterior chamber intraocular lenses in the absence of capsular support. [Összehajtható hátsó csarnoki múlencse toktámaszték nélküli másodlagos beültetése]. Szemészet, 2002, 139(4), 231234. [Hungarian]

[7] Benayoun, Y., Petitpas, S., Turki, K., et al.: Sutureless scleral intraocular lens fixation: report of nine cases and literature review. J. Fr. Ophtalmol., 2013, 36(8), 658-668.

[8] Scharioth, G. B., Prasad, S., Georgalas, I., et al.: Intermediate results of sutureless intrascleral posterior chamber intraocular lens fixation. J. Cataract Refract. Surg., 2010, 36(2), 254-259.

[9] Gicquel, J. J., Langman, M. E., Dua, H. S.: Iris claw lenses in aphakia. Br. J. Ophthalmol., 2009, 93(10), 1273-1275.

[10] Amar, L.: Posterior chamber iris claw lens. J. Cataract Refract. Surg., 1980, 6(3), 279

[11] Rijneveld, W. J., Beekhuis, W. H., Hassman, E. F., et al.: Iris claw lens: anterior and posterior iris surface fixation in the absence of capsular support during penetrating keratoplasty. J. Refract. Corneal Surg., 1994, 10(1), 14-19.

[12] Mohr, A., Hengerer, F., Eckardt, C.: Retropupillary fixation of the iris claw lens in aphakia. 1 year outcome of a new implantation techniques. Ophthalmologe, 2002, 99(7), 580-583.

[13] Soiberman, U., Pan, Q., Daoud, Y., et al.: Iris suture fixation of subluxated intraocular lenses. Am. J. Ophthalmol., 2015, 159(2), 353-359.

[14] Sekundo, W., Bertelmann, T., Schulze, S.: Retropupillary iris claw intraocular lens implantation technique for aphakia. Ophthalmologe, 2014, 111(4), 315-319.

[15] De Silva, S. R., Arun, K., Anandan, M., et al.: Iris-claw intraocular lenses to correct aphakia in the absence of capsule support. J. Cataract Refract. Surg., 2011, 37(9), 1667-1672.

[16] Gonnermann, J., Klamann, M. K., Maier, A. K., et al.: Visual outcome and complications after posterior iris-claw aphakic intraocular lens implantation. J. Cataract Refract. Surg., 2012, $38(12), 2139-2143$.

[17] Gonnermann, J., Amiri, S., Klamann, M., et al.: Endothelial cell loss after retropupillary iris-claw intraocular lens implantation. Klin. Monbl. Augenheilkd., 2014, 231(8), 784-787.

[18] Schöpfer, K., Berger, A., Korb, C., et al.: Position-dependent accommodative shift of retropupillary fixated iris-claw lenses. Graefes Arch. Clin. Exp. Ophthalmol., 2012, 250(12), 18271834.

[19] Hara, S., Borkenstein, A. F., Ehmer, A., et al.: Retropupillary fixation of iris-claw intraocular lens versus transscleral suturing fixation for aphakic eyes without capsular support. J. Refract. Surg., 2011, 27(10), 729-735.

(Szabó Antal dr., Budapest, Mária u. 39., 1085 e-mail: szaboa70@gmail.com) 